\title{
Low genetic diversity and significant structuring in the endangered Mentha cervina populations and its implications for conservation
}

\author{
Leandra Rodrigues ${ }^{\mathrm{a}, *}$, Cássio van den Berg ${ }^{\mathrm{b}}$, Orlanda Póvoa ${ }^{\mathrm{c}}$, Ana Monteiro ${ }^{\mathrm{a}}$ \\ ${ }^{a}$ DPPF - Secção de Herbologia, Centro de Botânica Aplicada à Agricultura (CBAA), Instituto Superior de Agronomia, Technical University \\ of Lisbon, Tapada da Ajuda, 1349-017 Lisboa, Portugal \\ ${ }^{\mathrm{b}}$ Departamento de Ciências Biológicas, Universidade Estadual de Feira de Santana, Av. Transnordestina s.n., 44036-900 Feira de Santana, \\ Bahia, Brazil \\ ${ }^{\mathrm{c}}$ Escola Superior Agrária de Elvas, Rua de Alcamim n 19, 7350-903 Elvas, Portugal
}

\section{A R T I C L E I N F O}

\section{Article history:}

Received 30 October 2012

Accepted 9 March 2013

Available online

\section{Keywords:}

Mentha cervina

Genetic diversity

Population structure

Conservation genetics

Endemic species

ISSR

\begin{abstract}
A B S T R A C T
Eighteen populations of the endangered aromatic and medicinal plant Mentha cervina (Lamiaceae) were sampled across its natural range, in the western half of the Iberian Peninsula, and inter-simple sequence repeats (ISSRs) markers were used to assess genetic diversity and population structure. M. cervina populations exhibited a relatively low genetic diversity (percentage of polymorphic loci PPB $=14.2-58.3 \%$, Nei's genetic diversity $H_{e}=0.135-0.205$, Shannon's information index $\left.I=0.08-0.33\right)$. However, the genetic diversity at species level was relatively high $\left(\mathrm{PPB}=98.3 \% ; H_{\mathrm{e}}=0.325 ; I=0.23\right.$ ). The results of the analysis of molecular variance indicated very structured populations, with $50 \%$ of the variance within populations, $44 \%$ among populations and $6 \%$ between regions defined by hydrographic basins, in line with the gene differentiation coefficient $\left(G_{S T}=0.532\right.$ ). A Mantel test did not find significant correlation between genetic and geographic distance matrices $(r=0.064)$, indicating that isolation by distance is not shaping the present genetic structure. The levels and patterns of genetic diversity in $M$. cervina populations were assumed to result largely from a combination of evolutionary history and its unique biological traits, such as breeding system, low capacity of dispersion, small effective size and habitat fragmentation. The high genetic differentiation among populations indicates the necessity of conserving the maximum possible number of populations. The results also provide information to select sites for ex situ conservation. Optimal harvesting strategies, cultivation and tissue culture should also be developed as soon as possible to guarantee sustainable use of the species under study.
\end{abstract}

(c) 2013 Elsevier Ltd. All rights reserved.

\section{Introduction}

Plants belonging to the genus Mentha (Lamiaceae) have evolved in nature through natural hybridization and selection, showing substantial variation in terms of their natural habitats, growth characteristics, and aromas (Tutin et al., 1972; Franco, 1984). In this genus, which includes many herbs that are used for medicines, cosmetics, and spices, particular attention has been given to some cultivated species, namely peppermint (Mentha piperita L.) and spearmints (Mentha spicata L. and Mentha cardiaca Baker) because of their essential oil (EO) compositions (Kokkini, 1991). The EOs from Mentha species have been used

\footnotetext{
* Corresponding author. Tel.: +35121 3653419; fax: +351213653195.

E-mail addresses: liarodrigues@isa.utl.pt, leandra_rodrigues@hotmail.com (L. Rodrigues).
} 
since ancient times for the treatment of many digestive tract diseases and in culinary (İşcan et al., 2002), and they are known to have antimicrobial properties (Flamini et al., 1999; Naigre et al., 1996). As such, mints are valuable crops with a substantial importance in the botanical economy and to the pharmaceutical industry.

Mentha cervina L. (commonly known as hart's pennyroyal) is an aromatic plant that is traditionally used in Portugal to flavour food dishes and for its medicinal properties, preventing different gastric disorders and inflammations of the respiratory tract (Monteiro et al., 2007; Póvoa et al., 2006; Rodrigues et al., 2008, 2012). It is a spreading herbaceous perennial with slender, lance-shaped, mid-green leaves and whorls of white or lilac flowers from midsummer into autumn. It has a western steno-Mediterranean distribution, and is found in France, Portugal, Spain, Morocco, Algeria and is presumably extinct in Italy (Rhazi and Grillas, 2010). It occurs mainly in river banks and other damp and wet places, which require a longer flooded period that is characteristic of the priority habitat Mediterranean temporary ponds (3170) (Silva et al., 2009). According to our field survey, areas that had previously been reported in herbaria as species habitats have now been severely deteriorated or fragmented largely due to anthropogenic activities (e.g., deforestation, overexploitation) and in one case the population had completely disappeared due to a hydroelectric dam construction (Póvoa et al., 2006). With the growth of commercial demands in recent years, the excessive harvesting from the wild (main source of plant material), overgrazing and the unfavorable conservation status of these habitats have shrunk the natural resources of $M$. cervina to a narrow distribution (Póvoa et al., 2006). Nowadays, it is considered to be decreasing in number and classified as Near Threatened in the IUCN Red List of Threatened Species (Rhazi and Grillas, 2010). A previous study (Rodrigues et al., 2008) found no chemical polymorphism in the EOs obtained in populations from different provenances. This surprising uniformity, in a species of a rather polymorphic genus, suggested a lack of variation and a need to assess genetic diversity. Up to date, no study has targeted the genetic diversity and structure, although this information is essential for the formulation of effective conservation strategies in threatened species (Holsinger and Gottlieb, 1991; Escudero et al., 2003; Shah et al., 2008).

The use of molecular markers to evaluate neutral genetic variation has become an important tool to study population genetics. Among various molecular tools, ISSRs (Inter-simple sequence repeats) have gained increasing interest because they have greater reliability and reproducibility of banding patterns when compared to RAPD (random amplified polymorphic DNA) primers (Culley and Wolfe, 2001), and at the same time, the cost of the analyses is relatively lower than that of some other markers such as AFLPs and microsatellites (Fang and Roose, 1997). Therefore, the recent use of ISSRs has been extensive in population genetics studies with wide applications in genetic diversity studies of species with conservation concerns (Esselman et al., 1999; Ge et al., 2005; McGlaughlin et al., 2002; Smith and Bateman, 2002; Xia et al., 2007), including Lamiaceae species (Liu et al., 2006; Mendes et al., 2009). ISSRs are especially useful in detecting diversity in closely related, or even clonal, individuals (Chen et al., 2006; Esselman et al., 1999; Han et al., 2007; Zietkiewicz et al., 1994).

Because of the medicinal and aromatic potential of this species (Gonçalves et al., 2007; Rodrigues et al., 2012) and current threats for its conservation, we in the present study use ISSRs to assess levels of variation, identify the degree of genetic differentiation among populations and provide guidelines for the conservation and sustainable use of this species in the range sampled.

\section{Materials and methods}

\subsection{Plant material}

In 2009 and 2010, several field trips were conducted across the geographic range of $M$. cervina. A total of 192 individuals, which correspond to 18 populations with different geographic origins were included in the analysis (Table 1). It is important to mention that despite our efforts to collect samples from a higher number of populations no more than 18 were found. Geographic distances between populations vary from 10 (between Mc37 and Mc38) to $487 \mathrm{~km}$ (between Mc33 and Mc46). Due to the limited availability of individuals in the populations, each population was evaluated by analyzing $10-15 \%$ of the individuals. These individuals were collected, throughout the entire range of each location, taking in to account distances between plants and accompaniment of the plant rhizomes to avoid duplication of individuals. From each sampled individual, fresh leaves were collected and dried in silica gel for subsequent DNA extraction. Vouchers for each population were deposited in the LISI Herbarium (Table 1).

\subsection{DNA extraction and ISSR-PCR amplification}

Total DNA was extracted from silica gel-dried leaves following the protocol of the plant mini kit (Quiagen), using 100$200 \mathrm{mg}$ of leaf material grounded to fine powder in liquid nitrogen. The quantity of DNA extracted was evaluated by electrophoresis in $0.8 \%$ agarose gels in TBE buffer (50 mM Trisma, $50 \mathrm{mM}$ boric acid, $2.5 \mathrm{mM}$ EDTA, pH 8.3), and each DNA sample was diluted to $10 \mathrm{ng} / \mu \mathrm{l}$ for PCR amplification.

All the tested primers were synthesized by Stab Vida (Lisbon, Portugal). Twenty primers were initially screened, and 10 of them, which yielded bright and discernible bands, were used for the analysis of all 192 samples.

PCR reactions were standardized and run on an I-cycler, Bio-Rad thermalcycler. For every $20 \mu \mathrm{L}$ reaction, 10 ng of DNA, $1 \times$ reaction buffer, $0.5 \mu \mathrm{M}$ of primer, $2 \mathrm{mM}$ of $\mathrm{MgCl}_{2}, 0.2 \mathrm{mM}$ of each dNTP, $2 \%$ of DMSO and 0.5 units Taq DNA polymerase were included. The amplification conditions were performed with the following program: initial denaturation at $94{ }^{\circ} \mathrm{C}$ for 
Table 1

Location of Mentha cervina populations and number of individuals sampled in the present study.

\begin{tabular}{|c|c|c|c|c|c|c|}
\hline \multirow[t]{2}{*}{ Populations } & \multirow[t]{2}{*}{ Sample sizes } & \multicolumn{5}{|l|}{ Specific sample collection sites } \\
\hline & & Localization & Altitude (m) & Latitude & Longitude & Hydrographic basin \\
\hline Mc10 & 9 & Ouguela, Campo Maior & 207 & $39^{\circ} 4^{\prime} 54.96^{\prime \prime} \mathrm{N}$ & $7^{\circ} 0^{\prime} 4.33^{\prime \prime} \mathrm{W}$ & Guadiana \\
\hline Mc29 & 9 & Ponte da Ajuda, Elvas & 166 & $38^{\circ} 46^{\prime} 32.02^{\prime \prime} \mathrm{N}$ & $7^{\circ} 10^{\prime} 29.61^{\prime \prime} \mathrm{W}$ & Guadiana \\
\hline Mc32 & 12 & Vilar seco, Miranda do Douro & 725 & $41^{\circ} 31^{\prime} 25.48^{\prime \prime} \mathrm{N}$ & $6^{\circ} 24^{\prime} 5.56^{\prime \prime} \mathrm{W}$ & Douro \\
\hline Mc33 & 13 & Póvoa, Miranda do Douro & 750 & $41^{\circ} 34^{\prime} 22.71^{\prime \prime} \mathrm{N}$ & $6^{\circ} 19^{\prime} 17.53^{\prime \prime} \mathrm{W}$ & Douro \\
\hline Mc34 & 5 & Bagaúste, Peso da Régua & 50 & $41^{\circ} 9^{\prime} 0.41^{\prime \prime} \mathrm{N}$ & $7^{\circ} 45^{\prime} 2.24^{\prime \prime} \mathrm{W}$ & Douro \\
\hline Mc35 & 14 & Escarigo, Figueira de Castelo Rodrigo & 560 & $40^{\circ} 50^{\prime} 34.73^{\prime \prime} \mathrm{N}$ & $6^{\circ} 49^{\prime} 33.62^{\prime \prime} \mathrm{W}$ & Douro \\
\hline Mc36 & 9 & Segura, Idanha-a-Nova & 235 & $39^{\circ} 49^{\prime} 11.06^{\prime \prime} \mathrm{N}$ & $6^{\circ} 58^{\prime} 52.99^{\prime \prime} \mathrm{W}$ & Tejo \\
\hline Mc37 & 16 & Salvaterra do Extremo, Idanha-a-Nova & 253 & $39^{\circ} 53^{\prime} 37.50^{\prime \prime} \mathrm{N}$ & $6^{\circ} 54^{\prime} 18.38^{\prime \prime} \mathrm{W}$ & Tejo \\
\hline Mc38 & 12 & Monfortinho, Idanha-a-Nova & 255 & $39^{\circ} 59^{\prime} 9.96^{\prime \prime} \mathrm{N}$ & $6^{\circ} 52^{\prime} 50.23^{\prime \prime} \mathrm{W}$ & Tejo \\
\hline Mc39 & 9 & Oledo, Idanha-a-Nova & 335 & $39^{\circ} 58^{\prime} 10.64^{\prime \prime} \mathrm{N}$ & $7^{\circ} 18^{\prime} 27.85^{\prime \prime} \mathrm{W}$ & Tejo \\
\hline Mc40 & 9 & Montalvão, Nisa & 116 & $39^{\circ} 39^{\prime} 50.86^{\prime \prime} \mathrm{N}$ & $7^{\circ} 32^{\prime} 19.27^{\prime \prime} \mathrm{W}$ & Tejo \\
\hline Mc41 & 9 & Valência de Alcântara & 313 & $39^{\circ} 28^{\prime} 1.17^{\prime \prime} \mathrm{N}$ & $7^{\circ} 12^{\prime} 24.16^{\prime \prime} \mathrm{W}$ & Tejo \\
\hline Mc42 & 8 & Torrão, Alcácer do Sal & 50 & $38^{\circ} 17^{\prime} 0.32^{\prime \prime} \mathrm{N}$ & $8^{\circ} 13^{\prime} 57.81^{\prime \prime} \mathrm{W}$ & Sado \\
\hline Mc43 & 15 & Entradas, Castro Verde & 154 & $37^{\circ} 44^{\prime} 36.51^{\prime \prime} \mathrm{N}$ & $7^{\circ} 58^{\prime} 44.60^{\prime \prime} \mathrm{W}$ & Guadiana \\
\hline Mc44 & 9 & La Codosera & 298 & $39^{\circ} 16^{\prime} 48.08^{\prime \prime} \mathrm{N}$ & $6^{\circ} 52^{\prime} 20.89^{\prime \prime} \mathrm{W}$ & Guadiana \\
\hline Mc45 & 9 & Alburquerque & 234 & $39^{\circ} 11^{\prime} 0.69^{\prime \prime} \mathrm{N}$ & $7^{\circ} 1^{\prime} 59.03^{\prime \prime} \mathrm{W}$ & Guadiana \\
\hline Mc46 & 14 & Gomes Aires, Almodôvar & 200 & $37^{\circ} 30^{\prime} 58.11^{\prime \prime} \mathrm{N}$ & $8^{\circ} 11^{\prime} 5.17^{\prime \prime} \mathrm{W}$ & Guadiana \\
\hline Mc47 & 11 & Castro Marim & 50 & $37^{\circ} 11^{\prime} 21.63^{\prime \prime} \mathrm{N}$ & $7^{\circ} 27^{\prime} 27.81^{\prime \prime} \mathrm{W}$ & Guadiana \\
\hline
\end{tabular}

4 min, followed by 40 cycles of $30 \mathrm{~s}$ at $94{ }^{\circ} \mathrm{C}$ to denature, $45 \mathrm{~s}$ at $48{ }^{\circ} \mathrm{C}$ to anneal the primers and 2 min at $72{ }^{\circ} \mathrm{C}$ to extend the primers. The last cycle was followed by $45 \mathrm{~s}$ at $94{ }^{\circ} \mathrm{C}, 45 \mathrm{~s}$ at $44{ }^{\circ} \mathrm{C}$ and a final extension at $72{ }^{\circ} \mathrm{C}$ for 5 min. A negative control with no DNA added was included in each PCR reaction. The amplified products were separated by electrophoresis in horizontal $1.5 \%$ agarose gels in $1 \times$ TBE buffer, at $100 \mathrm{~V}$ constant for $2 \mathrm{~h}$. The gels were stained with ethidium bromide $(0.5 \mu \mathrm{g} / \mathrm{ml})$, and visualized in ultraviolet light by using GEL DOC 2000 (Bio-Rad Gel Documentation System). The size of the amplified products was determined by comparison with 100 bp ladder. To verify the repeatability of the results, each PCR amplification and gel running was repeated twice, and only the amplified ISSR fragments present in both runs where considered.

\subsection{Data analysis}

Since ISSR markers are dominantly inherited, each band was assumed to represent the phenotype at a single diallelic locus (Williams et al., 1990). Consistently reproducible amplified ISSR fragments, between 300 and 1800 bp, were scored as present (1) our absent (0), each of which was treated as an independent character regardless of its intensity. Fragments of the same molecular weight were considered as the same locus.

The binary matrix (1/0), constructed with GELCOMPARII (Applied Maths), was used in parameter estimation with multiple algorithms and methodologies.

POPGENE 1.32 (Yeh et al., 1997) was used to calculate various genetic diversity parameters: percentage of polymorphic bands (PPB), expected heterozygosity $\left(H_{\mathrm{e}}\right)$, genetic diversity among populations $\left(D_{\mathrm{ST}}\right)$, Nei's (1973) coefficient of gene differentiation $\left(G_{S T}\right)$ and Shannon's index of diversity $(I)$.

Genetic diversity was also estimated as heterozygosity using the Bayesian approach of Holsinger et al. (2002), with the analysis program HICKORY version 1.1 (Holsinger and Lewis, 2003). Several runs were carried out with default sampling parameters (burn-in $=5,000$, sample $=25,000$ and thin 5 ) to ensure consistency of results and the full model was selected.

Grouping of the individuals using the Principal Coordinates Analysis (PCoA) was done with GENALEX 6 program (Peakall and Smouse, 2006). The additional measurement of partitioning genetic variation was obtained with the hierarchical analysis of molecular variance (AMOVA) analysis, using GENALEX 6 program, with 9999 permutations.

To illustrate the relationship among populations, the UPGMA (Unweighted Pair Group Method with Arithmetic mean) dendrograms were generated using the software package AFLPSURV (Vekemans et al., 2002) and PHYLIP (Felsenstein, 1989) based on Nei's genetic distance. This method was implemented with bootstrapping (1000 replicates), to assess the statistical support of each branch, and then majority-rule consensus trees were generated for each type of distance, using the modules NJ and CONSENSE in the PHYLIP package. The trees were viewed and drawn using TREEVIEW program (Page, 1996).

To further understand the relationships among populations, a Bayesian analysis with the software STRUCTURE (Pritchard et al., 2000) was used to reveal the number of genetic pools, assign individuals to populations and identify migrants and admixed individuals. Several runs were carried out with default sampling parameters (burn-in $=50.000$, number of MCMC runs after burn-in $=500.000$, using the admixture model and allele frequencies correlated) and K calculated by Evanno et al. (2005).

Geographical distances were calculated by Google Earth program. To test the correlation between Nei's genetic distance $(D)$ between populations and geographic distances (in km) among populations, a Mantel (Mantel, 1967) test was performed using GENALEX 6. Clonality was also tested using the multilocus genotypes analysis of the GENALEX 6 program. 
Table 2

Primers used in ISSR analysis of Mentha cervina and number of reproducible bands.

\begin{tabular}{lll}
\hline Primer code & Sequence $^{\mathrm{a}}$ & Reproducible bands \\
\hline ISSR1 & (CA)8RG & 21 \\
ISSR3 & (GA)8YT & 14 \\
ISSR4 & (GA)8YC & 16 \\
ISSR5 & (GA)8YG & 18 \\
ISSR6 & (AG)8YT & 15 \\
ISSR7 & (AG)8YC & 18 \\
ISSR8 & (AC)8YA & 16 \\
ISSR10 & (GT)8YC & 19 \\
ISSR15 & (GACAC)3 & 20 \\
ISSR898 & (CA)6-RY & 18 \\
& Mean & 17.5 \\
\hline
\end{tabular}

${ }^{\mathrm{a}} \mathrm{Y}=\mathrm{C}$ or $\mathrm{T} ; \mathrm{R}=\mathrm{A}$ or $\mathrm{G}$.

\section{Results}

\subsection{Genetic diversity}

Among the 20 ISSR primers tested for their ability to detect polymorphic bands (putative loci) in a subset of $M$. cervina samples, 10 primers generated interpretable polymorphic amplifications. In these 10 selected primers, the number of bands per primer (loci) varied from 14 (ISSR3) to 21 (ISSR1) with an average of 17.5 bands per primer (Table 2). Genetic diversity estimates from ISSR are summarized in Table 3. ISSR amplification of the 192 individuals, gave a total of 175 bands that could be scored, corresponding to an average of 79.9 fragments per individual. Of these bands, 172 were polymorphic. All the primers produced polymorphic bands when all 18 populations were considered. Private bands, absent in all populations except one, were not observed. The proportion of polymorphic bands at the population level varied from $14.2 \%$ (Mc34) to $64.6 \%$ (Mc43), with a mean of $44.4 \%$. This figure was $98.3 \%$ at the species level. Nei's gene diversity $\left(H_{\mathrm{e}}\right)$ and Shannon's information index $(I)$ showed a similar trend to PPB. As indicated by these three indices, the least genetically diverse populations are Mc29 $\left(H_{\mathrm{e}}=0.0802, I=0.117, \mathrm{PPB}=20.6 \%\right)$ and Mc34 $\left(H_{\mathrm{e}}=0.0512, I=0.076\right.$, $\mathrm{PPB}=14.2)$. The most diverse populations are Mc33 $\left(H_{\mathrm{e}}=0.222, I=0.332, \mathrm{PPB}=64 \%\right)$ and $\mathrm{Mc} 43\left(H_{\mathrm{e}}=0.219, I=0.328\right.$, PPB $=64.6)$ (Table 3).

\subsection{Genetic differentiation}

According to Nei's analysis of gene diversity, the percentages of genetic variation among $M$. cervina populations were $53.2 \%\left(G_{s t}\right)$ and $46 \%$ (Theta-B value, an estimate of $G_{s t}$ obtained by HICHORY analysis) which indicated elevated

Table 3

Measures of genetic diversity in the Mentha cervina species and for each population. PPB, percentage of polymorphic loci (at the 5\% level); I, Shanon's Information index; $H_{\mathrm{e}}$, Nei's gene diversity.

\begin{tabular}{|c|c|c|c|c|}
\hline \multirow[t]{2}{*}{ Population } & \multicolumn{2}{|l|}{ РРВ } & \multirow[t]{2}{*}{$I$} & \multirow[t]{2}{*}{$H_{\mathrm{e}}$} \\
\hline & Number & Percentage & & \\
\hline Mc10 & 101 & 57.7 & 0.29 & 0.193 \\
\hline Mc29 & 36 & 20.6 & 0.12 & 0.080 \\
\hline Mc32 & 102 & 58.3 & 0.31 & 0.208 \\
\hline Mc33 & 112 & 64.0 & 0.33 & 0.222 \\
\hline Mc34 & 25 & 14.2 & 0.08 & 0.051 \\
\hline Mc35 & 93 & 53.1 & 0.28 & 0.187 \\
\hline Mc36 & 57 & 32.6 & 0.18 & 0.124 \\
\hline Mc37 & 95 & 54.3 & 0.24 & 0.156 \\
\hline Mc38 & 91 & 52.0 & 0.24 & 0.159 \\
\hline Mc39 & 66 & 37.7 & 0.19 & 0.128 \\
\hline Mc40 & 47 & 26.9 & 0.14 & 0.097 \\
\hline Mc41 & 54 & 30.9 & 0.17 & 0.116 \\
\hline Mc42 & 63 & 36.0 & 0.20 & 0.131 \\
\hline Mc43 & 113 & 64.6 & 0.33 & 0.219 \\
\hline Mc44 & 64 & 36.6 & 0.18 & 0.117 \\
\hline Mc45 & 85 & 48.6 & 0.25 & 0.169 \\
\hline Mc46 & 105 & 60.0 & 0.29 & 0.193 \\
\hline Mc47 & 90 & 51.4 & 0.26 & 0.170 \\
\hline Mean & 78 & 44.4 & 0.23 & 0.151 \\
\hline Total & 172 & 98.3 & 0.23 & 0.325 \\
\hline
\end{tabular}


Table 4

Analysis of molecular variance (AMOVA) of intersimple sequence repeat (ISSR) data using GENEALEX, to determine the genetic structure for different hierarchical levels of the eighteen Mentha cervina populations. d.f., degree of freedom; SSD, sums of squares; MSD, mean square deviations; variance component estimates; percentage variation is the distribution of variation at a given level of hierarchy (among groups/among populations/within populations) and $P$ value is the significance of variance after 9999 permutations.

\begin{tabular}{|c|c|c|c|c|c|c|c|}
\hline Source of variation & d.f. & SSD & MSD & Variance component & Percentage & $\theta_{\mathrm{ST}}$ & $P$ value \\
\hline \multicolumn{8}{|l|}{ Mentha cervina } \\
\hline Among populations & 17 & 3104.54 & 182.62 & 15.671 & $49 \%$ & 0.493 & $<0.001$ \\
\hline Within populations & 174 & 2807.174 & 16.133 & 16.133 & $51 \%$ & & \\
\hline \multicolumn{8}{|c|}{ Four groups: Douro, Tejo, Sado, Guadiana } \\
\hline Among groups & 3 & 752.34 & 250.78 & 1.96 & $6 \%$ & 0.061 & $<0.001$ \\
\hline Among populations & 14 & 2352.20 & 168.01 & 14.26 & $44 \%$ & 0.469 & $<0.001$ \\
\hline Within populations & 174 & 2807.17 & 16.13 & 16.13 & $50 \%$ & 0.501 & $<0.001$ \\
\hline
\end{tabular}

interpopulation genetic differentiation. The AMOVA, that considered only one hierarchical level (Table 4), showed that most of the variation was found within populations (51\%), providing additional evidence for high genetic structuring of populations. Considering two levels, when populations were grouped by hydrographic basin, the proportion of total variance residing within populations was 50\%, among populations $44 \%$ and among basins $6 \%(P=0.001)$, which indicates that there is only a small proportion of the variation associated with grouping by river basin, even though it is statistically significant (Table 4). The nearly identical $\Phi_{\mathrm{ST}}$ from the AMOVA analysis $(0.469)$ and the $G_{\mathrm{ST}}$ from the POPGENE and from HICHORY analysis provide additional support of the statistics used in this study and robustness of the results.

\subsection{Genetic relationships}

The STRUCTURE analyses pointed out that the eighteen populations of $M$. cervina in the present study share 7 genetic pools, with migrants and admixed individuals. Mc37 and Mc38 are considered to share the same genetic pool in the two analyses, which is not surprising since they are geographically very close $(10 \mathrm{~km})$ and share the same river basin. The populations from the north region constitute another gene pool (Mc32, Mc33, Mc34 and Mc35) and 3 of them grouped together in the UPGMA tree (Fig. 2) (although with weak bootstrap support). The populations from the center-south are from two gene pools, that were also clustered in the UPGMA tree (although only with moderate bootstrap support) and the other 3 gene pools are found in the midland with weak and arbitrary clustering (Figs. 2 and 3 ).

The PCoA (Fig. 4) provided additional evidence for the highly structured populations, and in each population the individuals formed cohesive clusters. Overall the populations were grouped in 4 main groups, and the relationships were more or less in agreement to that implied by the Bayesian analysis (STRUCTURE) and the cluster analysis. The first two components, accounted for $48.87 \%$ (axis $1=27.15 \%$; axis $2=21.71 \%$ ) of the total variability. The clearest separation indicated in this analysis was of the southern populations (Mc42, Mc43, Mc44, Mc45, Mc46 and Mc47). The relationship of groups in the center and northern range presented broad overlap of populations (Mc10, Mc29, Mc32, Mc33, Mc34, Mc35, Mc39, and Mc41). The spread also indicated likely admixture of gene pools in some populations, namely Mc33, Mc35, and Mc43. This is in agreement with the mixed gene pools inferred for up to 25-30\% of these populations in the STRUCTURE analysis (Fig. 1). This admixture and the complex pattern of relationships which does not indicated strong geographical groups are corroborated by the Mantel test which did not find significant correlation between genetic and geographic distance matrices ( $r=0.064, P<0.298,9999$ permutations), indicating that the isolation by distance shaping the genetic structure pattern present in M. cervina population. Also, the analysis of clonality found no matching multilocus genotypes.

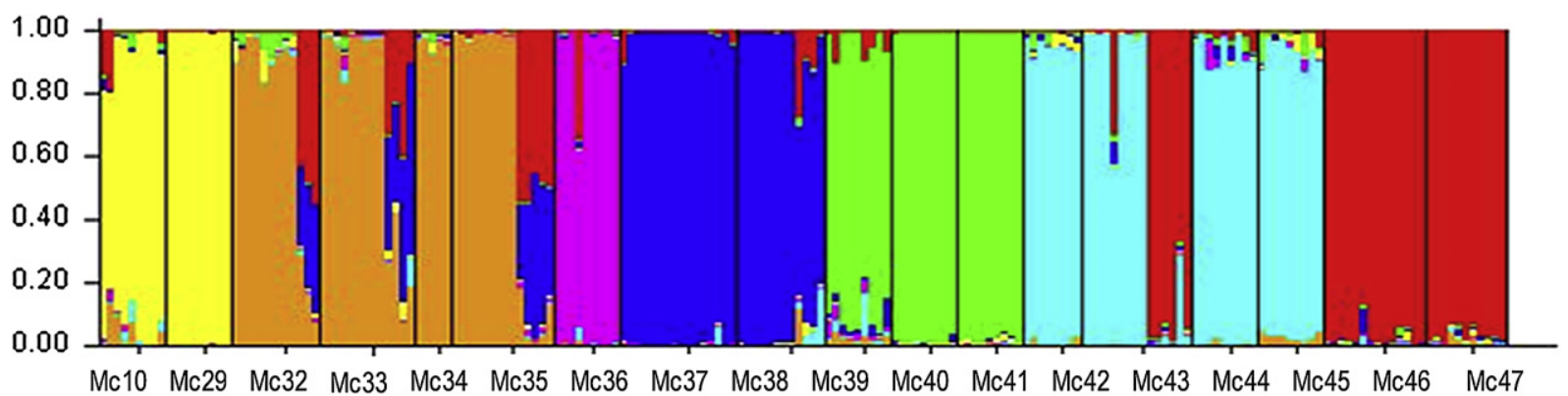

Fig. 1. Bayesian admixture proportions of $M$. cervina $(K=7)$. 


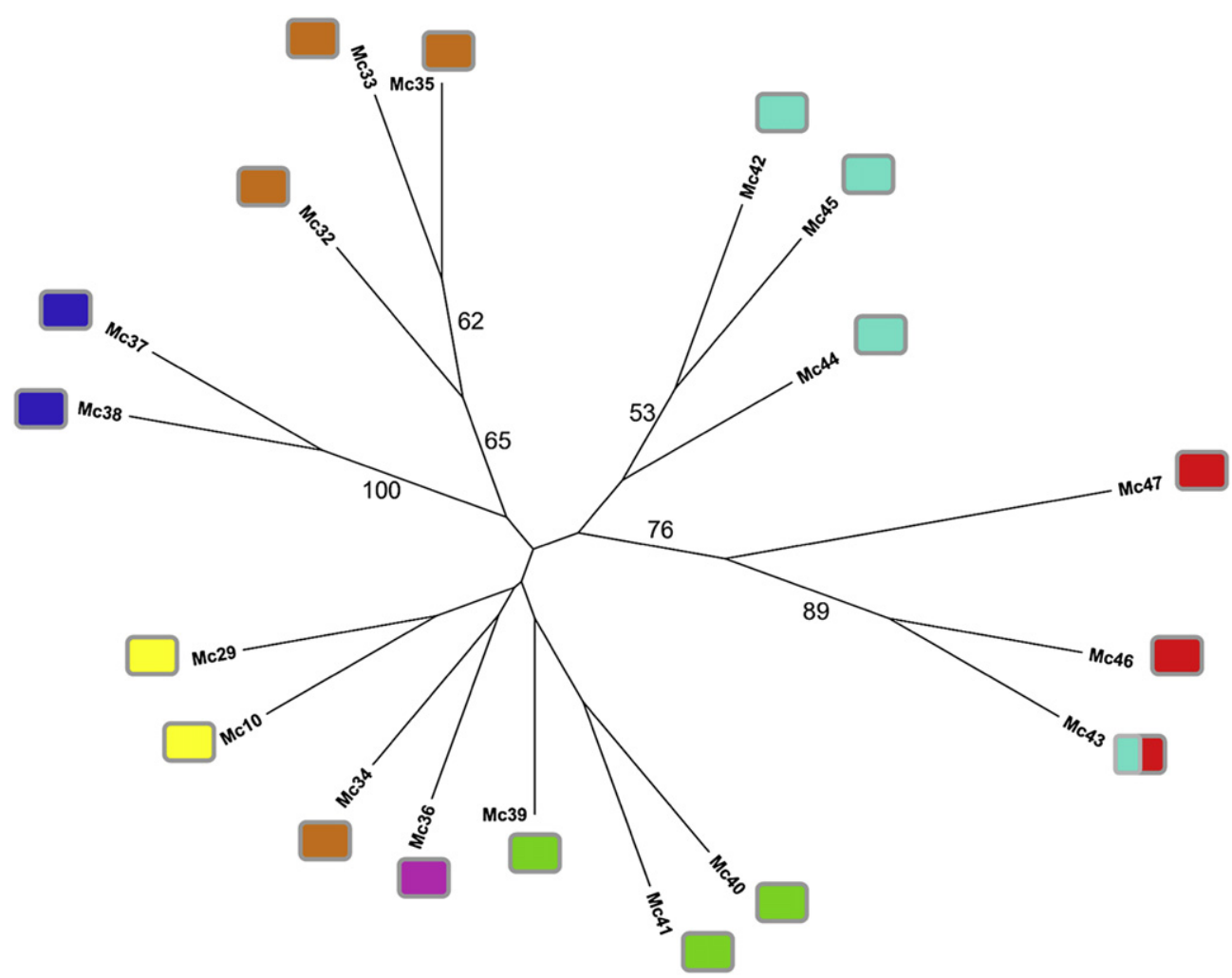

Fig. 2. UPGMA Dendrogram based on Nei's genetic distance matrix for Mentha cervina populations. One thousand replicates of bootstrapping analysis were used to assess the statistical support of each branch. Numbers in branches correspond to the bootstrap analyses ( $50 \%$ or more). Square colour blocks correspond to the structuring of populations according to the STRUCTURE analysis (Fig. 1). See Table 1 for population abbreviations. (For interpretation of the references to colour in this figure legend, the reader is referred to the web version of this article.)

\section{Discussion}

\subsection{Genetic diversity and differentiation}

Geographic range is usually regarded as an approximate measure of the total number of individuals of a species, so we can expect species with a wider distribution to tend to have higher genetic diversity than rare and endangered species (Karron, 1987; Sheeja et al., 2009; Xiao et al., 2004). However, many studies have shown that endangered or endemic species can also maintain high genetic diversity (Ellis et al., 2006; González-Astorga and Castillo-Campos, 2004; Luan et al., 2006; Zhang et al., 2010). M. cervina has a large extent of occurrence (from Italy to North Africa), but a restricted area of occupancy (approximately $600 \mathrm{~km}^{2}$ ) (Rhazi and Grillas, 2010). In Portugal, the same pattern is observed, and populations can be found from north to south, but in each location the area of occupancy is also very restricted, and most of the populations are found growing near our in river banks, with very limited number of individuals (10-1000).

The overall genetic diversity of $M$. cervina, based on ISSR analysis, is relatively high $\left(H_{\mathrm{e}}=0.323 ; I=0.226 ; \mathrm{PPB}=98.3 \%\right)$ at the species level, however, is relatively low at the population level. The PPB values ranged from 14.19 to $64.57 \%$, averaging $44.4 \%$, and the parameters $H_{\mathrm{e}}$ (ranging from 0.0802 to 0.222 , with an average of 0.151 ) and $I$ (ranging from 0.076 to 0.332 , with an average of 0.2264 ) display a similar trend. It is clear from data in Table 5 , that the two indices of genetic diversity (PPB and $H_{\mathrm{e}}$ ) have the highest value for $M$. cervina at the species level in comparison with all other species. However, at the population level, the values are lower than the genetic diversity reported for other populations of Lamiaceae species and are consistent with other populations of endangered species (Table 5 and references there in). The high overall genetic diversity displayed by the species itself can be explained mostly by differences among populations due to the high genetic structure.

The present diversity pattern could not be explained by the isolation by- distance model, as revealed by Mantel test $(r=0.064)$. Although evolutionary divergence could be associated with rivers, because they are believed to be major geographical barriers that might largely hinder gene flow via seed and pollen dispersal among populations (Pfeifer and Jetschke, 2006), they also can act as dispersal routes for species that grow nearby or in the water. The AMOVA analysis revealed a weak partitioning of variation associated with the share of the river basin of populations, suggesting that each population analyzed is genetically defined and structured as a distinct genetic pool. Therefore, although highly structured, the 


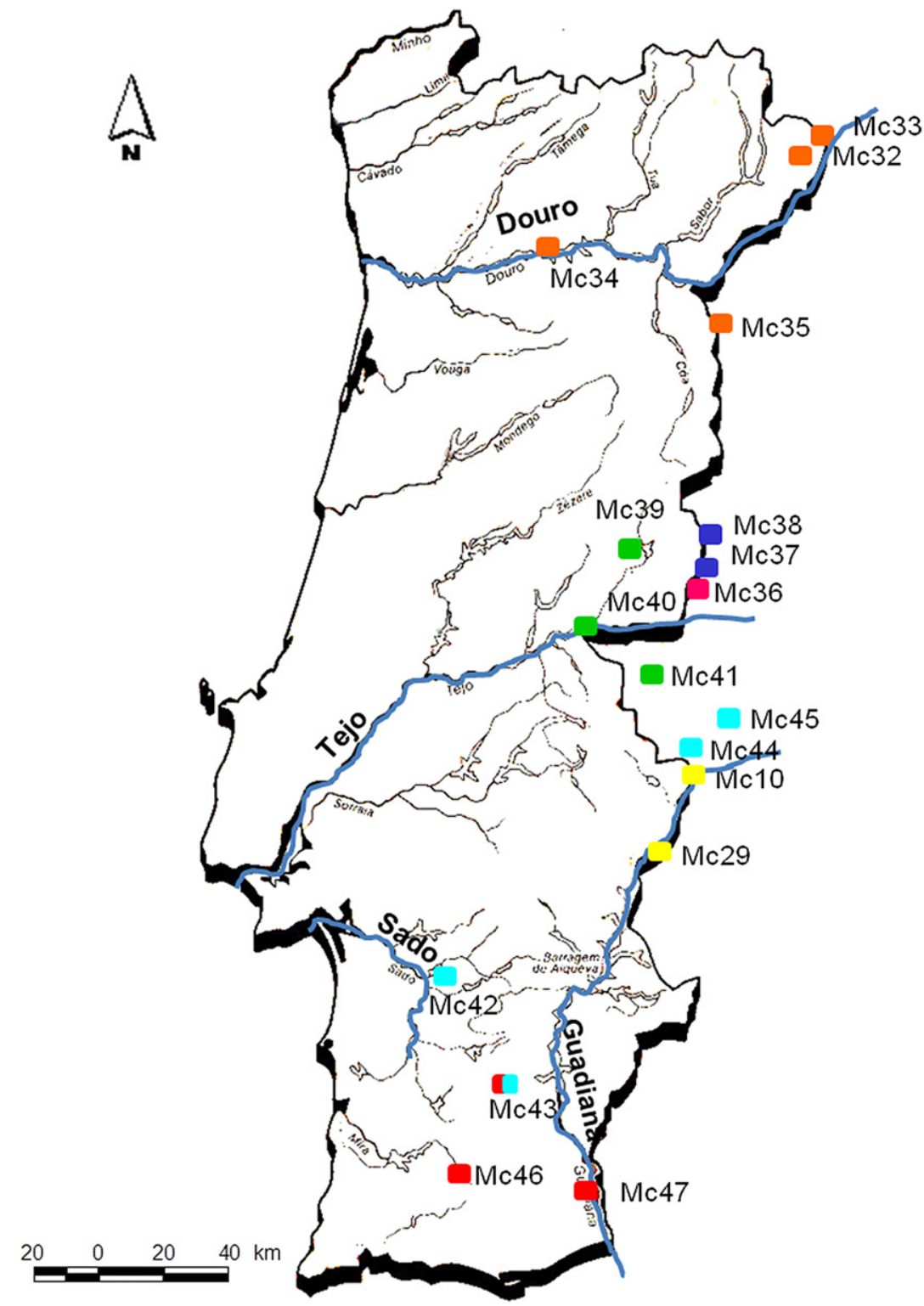

Fig. 3. Map of Portugal with the location of Mentha cervina populations analysed. Square colour blocks correspond to the structuring of populations according to the STRUCTURE analysis. See Table 1 for population abbreviations. (For interpretation of the references to colour in this figure legend, the reader is referred to the web version of this article.)

populations of M. cervina are structured without a strong geographical pattern and in a more or less stochastic fashion, indicating a predominance of stochastic processes shaping the genetic variation.

M. cervina was usually observed in severely fragmented habitats and with small population sizes (from 10 to 1000 individuals), which make this species extremely vulnerable to fluctuations in climate and habitat disturbance (Travis et al., 1996). Indeed, populations with small population size and severe human disturbance (MC29, MC34, MC36 and Mc40), showed the lowest genetic diversity, while population MC33 and MC43, with relatively large population size and limited human disturbance, showed higher genetic diversity. It seems that populations in fragmented habitats and small effective size, are more subjected to stochastic events, genetic drift and inbreeding (Hartl and Clark, 1997), leading to a low genetic diversity and the high genetic structure pattern observed.

Another effect of habitat fragmentation and other human disturbance is being reported on plant breeding systems, with an increase in self-fertilization (Aguilar et al., 2008; Eckert et al., 2009). In plants, breeding system can significantly affect genetic diversity and it's partitioning within and among populations (Hamrick and Godt, 1996; Nybom, 2004). Selfing species are expected to have reduced effective population sizes (Ingvarsson, 2002), to have lower genetic diversity within populations and a partition of diversity of about $50 \%$, whereas outcrossing species partition on average $20 \%$ among populations (Evans et al., 2000; 


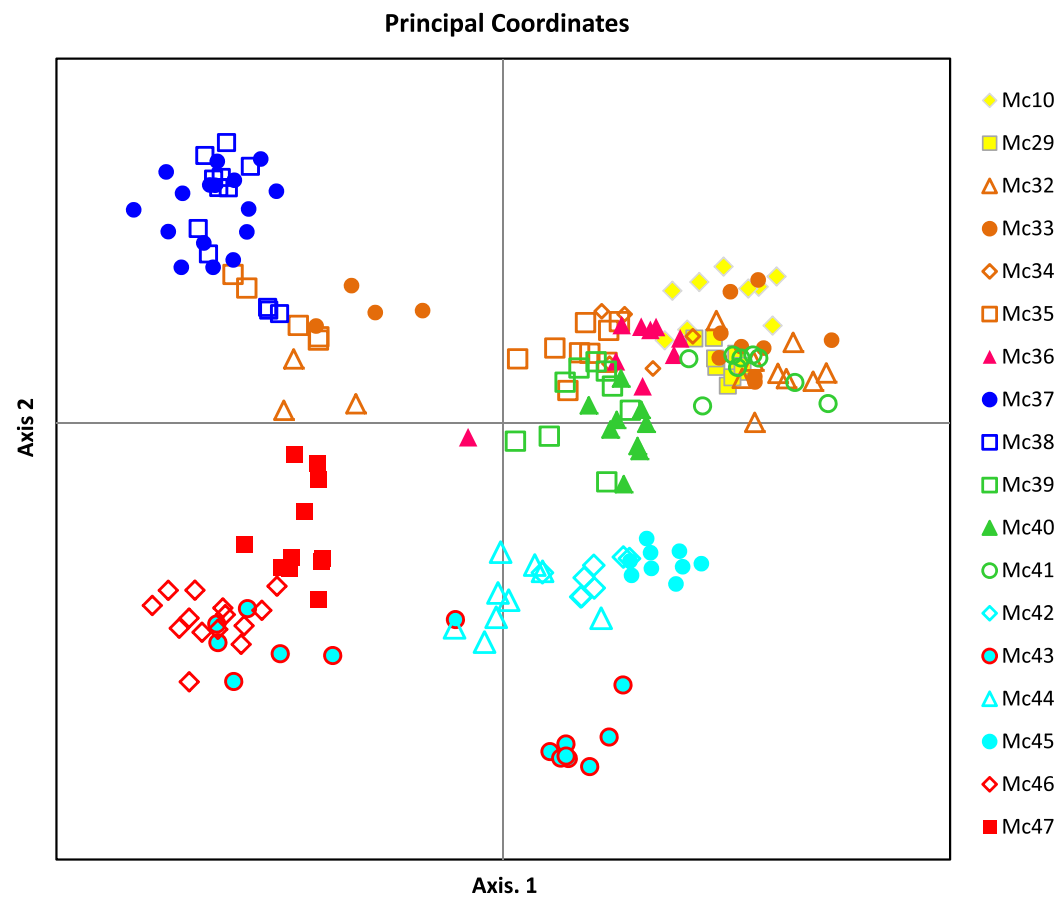

Fig. 4. Representation of the scores on the first two axes of the principal coordinate analysis (PCoA) from the matrix of genetic distances of 192 individuals from 18 populations of $M$. cervina, based on 175 ISSR loci. Percentage of variance accumulated on the first two axes $=48.87 \%$ (axis $1=27.15 \%$, axis $2=21.71 \%$ ). For population names see Table 1.

Hamrick and Godt, 1989; Nybom and Bartish, 2000; Tarayre and Thompson, 1996). Although there are no reports on the breeding system of M. cervina, it is likely an outcrossing species based on the breeding features of its closely related species (Judd et al., 1999), and so, most of the genetic diversity of M. cervina was expected to be partitioned within populations (Hamrick and Godt, 1996). Instead, the intra- and inter-population genetic partitioning were on average $51 \%$ and $49 \%$, respectively.

M. cervina exhibits vigorous vegetative growth by rhizomes and an almost absent seed production (personal observations). Furthermore, seed dispersal is not likely to be very efficient in $M$. cervina because seeds are very small and light and lack any apparent dispersal structures.

Based on the ISSR data and on our field survey of habitats, the low levels of variability within populations and the high genetic structuring among populations probably resulted from 1) genetic drift and inbreeding dictated by fragmented habitat

Table 5

Genetic diversity measurements in Mentha cervina, in other Lamiaceaes and in endangered species. PPB percentage of polymorphic loci, $H_{\mathrm{e}}$ Nei's gene diversity: Numbers between () correspond to population values, and the other number to the mean value of the populations; $G_{\text {st }}$ coefficient of gene differentiation.

\begin{tabular}{|c|c|c|c|c|c|c|c|}
\hline & \multicolumn{2}{|l|}{ PPB } & \multicolumn{2}{|l|}{$H_{\mathrm{e}}$} & \multirow[t]{2}{*}{$G_{\text {st }}$} & \multirow[t]{2}{*}{ Methodology } & \multirow[t]{2}{*}{ Reference } \\
\hline & Species & Population & Species & Population & & & \\
\hline \multicolumn{8}{|l|}{ Lamiaceae } \\
\hline Mentha cervina & 98.29 & $44.4(14.2-64.6)$ & 0.325 & $0.151(0.08-0.222)$ & 0.532 & ISSR & Present study \\
\hline Lamiophlomis rotata & 96.7 & $51.8(37.9-69.2)$ & 0.291 & 0.291 & 0.430 & ISSR & Liu et al., 2006 \\
\hline Lamiophlomis rotata & 93.13 & $47.5(23.6-64.4)$ & 0.287 & 0.287 & 0.422 & RAPD & Liu et al., 2006 \\
\hline Hemigenia exilis & 97.00 & $72.0(45.5-91.7)$ & 0.27 & $0.39(0.355-0.431)$ & & RAPD & Mattner et al., 2002 \\
\hline Phlomis purpurea & & & 0.085 & 0.085 & & Allozymes & Aparicio et al., 2000 \\
\hline Phlomis composita & & & 0.079 & 0.079 & & Allozymes & Aparicio et al., 2000 \\
\hline Mentha pulegium & & $72.0(60-90)$ & 0.229 & $0.30(0.40-0.21)$ & & Allozymes & Ben and Boussaid, 2004 \\
\hline \multicolumn{8}{|l|}{ Endangered species } \\
\hline Cycas guizhouensis & 38.9 & $14.2(8.9-20.5)$ & 0.1082 & $0.0597(0.036-0.088)$ & & ISSR & Xiao et al., 2004 \\
\hline Camellia nitidissina & 75.24 & 42.4 & 0.2302 & 0.098 & 0.575 & ISSR & Bin et al., 2005 \\
\hline Camellia nitidissina & 63.22 & $18.8(11.5-24,1)$ & 0.1561 & $0.083(0.051--0.105)$ & 0.406 & ISSR & Xiao et al., 2008 \\
\hline Sinocalycanthus chinensis & 73.08 & 23.65 & 0.1987 & 0.084 & 0.578 & ISSR & Jin and Li 2007 \\
\hline Emmenopterys henryi & 56.05 & 22.56 & 0.191 & $0.071(0.053-0.105)$ & & ISSR & $\mathrm{Li}$ and Jin 2008 \\
\hline Gynostemma pentaphyllum & 96.4 & $8.9(1-25.3)$ & 0.2624 & $0.026(0.004-0.084)$ & 0.889 & ISSR & Wang et al., 2008 \\
\hline Saruma henryi & 73.7 & $22.8(10.3-36.6)$ & 0.260 & $0.086(0.045-0.124)$ & 0.690 & ISSR & Zhou et al., 2010 \\
\hline Vellozia gigantea & 88.8 & $56.6(47.2-68.5)$ & 0.256 & $0.183(0.140-0.225)$ & 0.280 & ISSR & Lousada et al., 2011 \\
\hline Astragalus nitidiflorus & 51.3 & $31.8(28.2-37.2)$ & 0.171 & $0.129(0.109-0.146)$ & 0.242 & ISSR & Vicente et al., 2011 \\
\hline
\end{tabular}


and small population sizes and 2) a low seed setting/germination/dispersion. In this context, the genetic diversity within population is mostly dependent on the first colonizing plants, and works in a very stochastic manner.

Although ISSRs markers are considered to be neutral and thus to provide no direct assessment of fitness, the diminished genetic diversity found within these populations, despite the high genetic diversity at the species level, might explain the lack of phytochemical diversity at the essential oil composition reported in Rodrigues et al. (2008). Nevertheless, to better understand the patterns of genetic diversity and structure further studies on the quantitative genetic differentiation, species breeding system and the effects of habitat fragmentation and other human disturbance on plant diversity will be needed.

\subsection{Implications for conservation}

The main goal of current conservation plans is mainly focus in maintaining species diversity, in detriment of the intraspecific genetic diversity (Margules and Pressey, 2000). Nevertheless, the intraspecific genetic diversity is the primary source of diversity and has suffered extinction rates three to eight times higher than species extinction rates (Hughes et al., 1997). In M. cervina, the high genetic diversity at the species level is coupled with significant structuring and very low diversity at the population level. For this reason for satisfactory conservation of genetic diversity it should be considered the intraspecific genetic diversity together with the habitat preservation in an integrative approach to species conservation.

In situ conservation is usually the preferred strategy for most wild plant species because allows populations to continue to be exposed to evolutionary processes in its natural habitat enabling the perpetuation and integration of co-adapted gene complexes, especially in producing new resistances to stresses (pests, diseases, climate changes) (Aga et al., 2005; Vinceti et al., 2004). Because $M$. cervina populations currently face the problem of conservation link to the disappearance of the species habitat (general problem of wetland conservation) and the harvest pressure on wild populations, preserving and expanding the habitat at each site to allow natural expansion of populations would be a good strategy for its conservation before populations become too small to persist naturally. According to the field survey, the construction of a hydroelectric dam has flooded the habitat of population Mc29, and so this population is already lost. Given that Mc10 is genetically more close to Mc29, the survival of this population should be assigned priority for the conservation plan.

In conservation biology, genetic diversity is recognized as an important criterion to consider when prioritizing populations for protection, but conservation and management measures in a long-term perspective should ensure that the vast majority of the diversity is preserved for upcoming adaptations (i.e. the highest neutral genetic diversity that may be the future target of natural selection) (McKay and Latta, 2002). And so, preserve the populations that together maximize the species genetic diversity should be applied in opposition to the traditional approach of targeting populations that are the most diverse individually. Considering the different genetic pools found it would be worthy to prioritize populations in a matter as to represent all the genetic pools, and within these the most diverse populations. Populations Mc10, Mc33, Mc36, Mc37, Mc39 and Mc45 can be good representatives.

In order to increase the genetic diversity of M. cervina populations, the transfer of individuals between populations should also be considered. Nevertheless, one should take into consideration that when populations are genetically highly structured, outbreeding depression might be a potential genetic threat for already weakened populations (Sagvik et al., 2005). And so, it may be wiser to protect a network of populations that exchange genetic material and are able to reinforce each other. Given the genetic clusters found, we can suggest that only individuals within these clusters should be exchanged.

Moreover, considering that the samples collected in this study provide a snapshot of the species distribution area as a whole in Portugal, it would be also wise to preserve populations in different regions in order to limit population declines caused by large-scale environmental catastrophes and also to harbour possible local adaptative variation. Commercial harvesting of M. cervina for essential oil extraction is one of the major forms of its disturbance because its composition determines that the most favorable harvesting season is before seed dispersion. To meet the commercial demand for this herb and reduce harvesting pressure in $M$. cervina wild populations, cultivation by seed and tissue culture, should be carried out as soon as possible as an alternative source of raw materials for trade.

Not only in Portugal, but also throughout its range, the populations of $M$. cervina are suffering severe and rapid declines and are therefore classified as Near Threatened in the IUCN Red List of Threatened Species (Rhazi and Grillas, 2010). The populations once known in Italy (Abruzzi) are presumed extinct. In France, it is known in six departments and is considered as vulnerable (one level upward of the Near Threatened, according to the IUCN nomenclature) and in North Africa it is considered rare (Rhazi and Grillas, 2010). Taking in to account the levels of diversity of Portuguese M. cervina populations, its threatened habitat status and the high harvesting pressures, it is also suggested to consider M. cervina as Endangered Species in Portugal in one of the forthcoming volumes of the IUCN Red List of Threatened Species.

Enlarge sampling to represent the full distribution range of $M$. cervina and complete the genetic landscape picture of this species is needed for the effective conservation management of this medicinal and aromatic species.

\section{Acknowledgements}

The financial support of Fundação para a Ciência e Tecnologia (FCT/CBAA and PhD Grant SFRH/BD/38143/2007 of Leandra Sofia Rodrigues) is gratefully acknowledged. The authors also thank the anonymous reviewers for their valuable suggestions and comments on the manuscript. 


\section{References}

Aga, E., Bekele, E., Bryngelsson, T., 2005. Inter-simple sequence repeat (ISSR) variation in forest coffee trees (Coffea arabica L.) populations from Ethiopia. Genetica 124, 213-221.

Aguilar, R., Quesada, M., Ashworth, L., Herrerias-Diego, Y., Lobo, J., 2008. Genetic consequences of habitat fragmentation in plant populations: susceptible signals in plant traits and methodological approaches. Mol. Ecol. 17, 5177-5188.

Aparicio, A., Albaladejo, R.G., Porras, M., Ceballos, G., 2000. Isozyme evidence for natural hybridization in Phlomis (Lamiaceae): hybrid origin of the rare P. x margaritae. Ann. Bot. 85, 7-12.

Ben Fadhel, N., Boussaid, M., 2004. Genetic diversity in wild Tunisian populations of Mentha pulegium L. (Lamiaceae). Genet. Resourc. Crop Ev. 51, 309-321. Bin, X.Y., Tang, S.Q., Zhou, J.Y., et al., 2005. ISSR analysis on genetic diversity of Camellia nitidissima Chi (Theaceae) in China. J. Wuhan. Bot. Res. 23, 20-26.

Chen, W.R., Gituru, Y.H., Wang, Q.F., 2006. The extent of clonality and genetic diversity in the rare Caldesia grandis (Alismataceae): comparative results for RAPD and ISSR markers. Aquat. Bot. 84, 301-307.

Culley, T.M., Wolfe, A.D., 2001. Population genetic structure of the cleistogamous plant species Viola pubescens Aiton (Violaceae), as indicated by allozyme and ISSR molecular markers. Heredity 86, 545-556.

Eckert, C.G., Kalisz, S., Geber, M.A., Sargent, R., Elle, E., Cheptou, P.-O., Goodwillie, C., Johnston, M.O., Kelly, J.K., Moeller, D.A., Porcher, E., Ree, R.H., VallejoMarín, M., Winn, A.A., 2009. Plant mating systems in a changing world. Trends Ecol. Evol. 25, 35-43.

Ellis, J.R., Pashley, C.H., Burke, J.M., McCauley, D.E., 2006. High genetic diversity in a rare and endangered sunflower as compared to a common congener. Mol. Ecol. 15, 2345-2355.

Escudero, A., Iriondo, J.M., Torres, M.E., 2003. Spatial analysis of genetic diversity as a tool for plant conservation. Biol. Conserv. 113, $351-365$.

Esselman, E.J., Jianqiang, L., Crawford, D.J., Wimdus, J.L., Wolfe, A.D., 1999. Clonal diversity in the rare Calamagrostis porteri ssp. Insperata (Poaceae): comparative results for allozymes and random amplified polymorphic DNA (RAPD) and inter simple sequence repeat (ISSR) markers. Mol. Ecol. 8 , $443-451$.

Evanno, G., Regnaut, S., Goudet, J., 2005. Detecting the number of clusters of individuals using the software STRUCTURE: a simulation study. Mol. Ecol. 14, $2611-2620$.

Evans, M.E.K., Dolan, R.W., Menges, E.S., Gordon, D.R., 2000. Genetic diversity and reproductive biology in Warea carteri (Brassicaceae), a narrowly endemic Florida scrub annual. Am. J. Bot. 87, 372-381.

Fang, D.Q., Roose, M.L., 1997. Identification of closely related citrus cultivars with inter-simple sequence repeat markers. Theor. Appl. Genet. 95, $408-417$.

Felsenstein, J., 1989. PHYLIP phylogeny inference package (version 3.2). Cladistics 5, 164-166.

Flamini, G., Cioni, P.L., Puleio, R., Morelli, I., Panizzi, L., 1999. Antimicrobial activity of the essential oil of Calamintha nepeta and its constituent pulegone against bacteria and fungi. Phytother. Res. 13, 349-351.

Franco, J.A., 1984. Nova Flora de Portugal (Continente e Açores), vol. II. Lisboa.

Ge, X.J., Zhou, X.L., Zhong, C.L., Hsu, T.W., Schaal, B.A., Chiang, T.Y., 2005. Low genetic diversity and significant population structuring in the relict Amentotaxus argotaenia complex (Taxaceae) based on ISSR fingerprinting. J. Plant Res. 118, 415-422.

González-Astorga, J., Castillo-Campos, G., 2004. Genetic variability of the narrow endemic tree Antirhea aromatic Castillo-Campos and Lorence, (Rubiaceae, Guettardeae) in a tropical forest of Mexico. Ann. Bot. 93, 521-528.

Gonçalves, M., Vicente, A., Cavaleiro, C., Salgueiro, L., 2007. Composition and antifungal activity of the essential oil of Mentha cervina from Portugal. Nat. Prod. Res. 21, 867-871.

Hamrick, J.L., Godt, M.J.W., 1989. Allozyme diversity in plant species. In: Brown, A.H.D., Clegg, M.T., Kahler, A.L., Weir, B.S. (Eds.), Plant Population Genetics, Breeding, and Genetic Resources. Sinauer Associates, Sunderland, Massachusetts, USA, pp. 43-63.

Hamrick, J.L., Godt, M.J.W., 1996. Effect of life history traits on genetic diversity in plant species. Philos Trans. R. Soc. London. B. Biol. Sci. 351, 1291-1298.

Han, Y.C., Teng, C.Z., Zhong, S., Zhou, M.Q., Hu, Z.L., Song, Y.C., 2007. Genetic variation and clonal diversity in populations of Nelumbo nucifera (Nelumbonaceae) in central China detected by ISSR markers. Aquat. Bot. 86, 69-75.

Hartl, D.L., Clark, A.G., 1997. Principles of Population Genetics, third ed. Sinauer, Sunderland.

Holsinger, K.E., Gottlieb, L.D., 1991. Conservation of rare and endangered plants: principles and prospects. In: Falk, D.A., Holsinger, K.E. (Eds.), Genetics and Conservation of Rare Plants. Oxford Univ. Press, New York, pp. 195-208.

Holsinger, K.E., Lewis, P.O., 2003. Hickory (Version 1.1). Department of Ecology \& Evolutionary Biology. The University of Connecticut, Connecticut.

Holsinger, K.E., Lewis, P.O., Dey, D.K., 2002. A Bayesian approach to inferring population structure from dominant markers. Mol. Ecol. 11, 1157-1164.

Hughes, J.B., Daily, G.C., Ehrlich, P.R., 1997. Population diversity: its extent and extinction. Science 278, 689-692.

Ingvarsson, P.K., 2002. A metapopulation perspective on genetic diversity and differentiation in partially self-fertilizing plants. Evolution 56 , $2368-2373$.

İscan, G., Krmer, N., Kürkcüolu, M., Hüsnü, K., Bașer, C., Demrc, F., 2002. Antimicrobial screening of Mentha piperita essential oils. J. Agric. Food Chem. 50, 3943-3946.

Jin, Z.X., Li, J.M., 2007. ISSR analysis on genetic diversity of endangered relic shrub Sinocalycanthus chinensis. Chin. J. Appl. Ecol. 18, 247-253.

Judd, W.S., Campbell, C.S., Kellogg, E.A., Stevens, P.F., 1999. Plant Systematics: a Phylogenetic Approach. Sinauer, Sunderland.

Karron, J.D., 1987. A comparison of levels of genetic polymorphism and self-compatibility in geographically restricted and widespread plant congeners. Evol. Ecol. 1, 47-58.

Kokkini, S., 1991. Chemical races within the genus Mentha L. In: Liskens, H.F., Jackson, J.F. (Eds.), Essential Oils and Waxes. Springer-Verlag, Berlin, pp. 63-78.

Li, J.M., Jin, Z.X., 2008. Genetic structure of endangered Emmenopterys henryi Oliv. based on ISSR polymorphism and implications for its conservation. Genetica 133, 227-234.

Liu, J., Wang, L., Geng, Y., Wang, Q., Luo, L., Zhong, Y., 2006. Genetic diversity and population structure of Lamioplomis rotate (Lamiaceae), an endemic species of Qinghai-Tibet plateau. Genetica 128, 385-394.

Lousada, J.M., Borb, E.L., Ribeiro, K.T., Ribeiro, L.C., Lovato, M.B., 2011. Genetic structure and variability of the endemic and vulnerable Vellozia gigantea (Velloziaceae) associated with the landscape in the Espinhaço Range, in southeastern Brazil: implications for conservation. Genetica 139, 431-440.

Luan, S., Chiang, T.Y., Gong, X., 2006. High genetic diversity vs. low genetic differentiation in Nouelia insignis (Asteraceae), a narrowly distributed and endemic species in China, revealed by ISSR fingerprinting. Ann. Bot. (Lond) 98, 583-589.

Mantel, N., 1967. The detection of disease clustering and a generalized regression approach. Cancer. Res. 27, $209-220$.

Margules, C.R., Pressey, R.L., 2000. Systematic conservation planning. Nature 405, 243-253.

Mattner, J., Zawko, G., Rossetto, M., Krauss, S.L., Dixon, K.W., Sivasithamparam, K., 2002. Conservation genetics and implications for restoration of Hemigenia exilis (Lamiaceae), a serpentine endemic from Western Australia. Conserv. Biol. 107, 37-45.

McGlaughlin, M., Karoly, K., Kaye, T., 2002. Genetic variation and its relationship to population size in reintroduced populations of pink sand verbena, Abronia umbellata subsp. breviflora (Nyctaginaceae). Conserv. Genet. 3, 411-420.

McKay, J.K., Latta, R.G., 2002. Adaptive population divergence: markers, QTL and traits. Trends Ecol. Evol. 17, 285-291.

Mendes, M., Trindade, H., Figueiredo, A.C., Pedro, L.G., Barroso, J.G., 2009. Chaerophyllum azoricum Trel. grown in the Azores archipelago, Portugal: evaluation of the genetic diversity using molecular markers and comparison with volatile oils profiles. Flavour Fragr. J. $24,259-265$.

Monteiro, A., Póvoa, O., Marinho, S., Rodrigues, L., Monteiro, P., 2007. Mentha pulegium e Mentha cervina, Os Poejos na boa Cozinha Portuguesa. ISA Press, Lisboa.

Naigre, R., Kalck, P., Roques, C., Roux, I., Michel, G., 1996. Comparison of antimicrobial properties of monoterpenes and their carbonylated products. Planta Med. 62, 275-277.

Nei, M., 1973. Analysis of genetic diversity in subdivided populations (population structure/genetic variability/hetrozygosity/gene differentiation). Proc. Natl. Acad. Sci. U S A 70, 3321-3323. 
Nybom, H., 2004. Comparison of different nuclear DNA markers for estimating intraspecific genetic diversity in plants. Mol. Ecol. 13, 1143-1155.

Nybom, H., Bartish, I.V., 2000. Effects of life history traits and sampling strategies on genetic diversity estimates obtained with RAPD markers in plants. Perspect Plant Ecol. Evol. Syst. 3, 93-114.

Page, R.D.M., 1996. TREEVIEW: an application to display phylogenetic trees on personal computers. Comput. Appl. Biosci. 112, 357-358.

Peakall, R.O.D., Smouse, P.E., 2006. GENALEX 6: genetic analysis in Excel. Population genetic software for teaching and research. Mol. Ecol. Notes 6, 288-295.

Pfeifer, M., Jetschke, G., 2006. Influence of geographical isolation on genetic diversity of Himantoglossum hircinum (Orchidaceae). Folia Geobot. 41, 3-20.

Póvoa, O., Farinha, N., Marinho, S., Nunes, P., Godinho, D., Mata, F., Rodrigues, L., Monteiro, A., 2006. Pennyroyal (Mentha pulegium L.) and Hart's Pennyroyal (Mentha cervina L.) biodiversity in Alentejo. Acta Hort. 723, 91-97.

Pritchard, J., Stephens, M., Donnelly, P., 2000. Inference of population structure using multilocus genotype data. Genetics 155 , 945-959.

Rhazi, L., Grillas, P. 2010. Mentha cervina. In: IUCN 2011. IUCN Red List of Threatened Species. Version 2011.2. www.iucnredlist.org. Downloaded on 31 January 2012.

Rodrigues, L., Monteiro, P., Póvoa, O., Teixeira, G., Moldão, M., Figueiredo, A.C., Monteiro, A., 2008. Morphology of secretory structures and essential oil composition in Mentha cervina L. from Portugal. Flavour Fragr. J. 23, 340-347.

Rodrigues, L., Duarte, A., Figueiredo, A.C., Brito, L., Teixeira, G., Moldão, M., Monteiro, A., 2012. Chemical composition and antibacterial activity of the essential oils from the medicinal plant Mentha cervina L. grown in Portugal. Med. Chem. Res. 21, 3485-3490.

Sagvik, J., Uller, T., Olsson, M., 2005. Outbreeding depression in the common frog, Rana temporaria. Conserv. Genet. 6, $205-211$.

Shah, A., Li, D.Z., Möller, M., Gao, L.M., Hollingsworth, M.L., Gibby, M., 2008. Delimitation of Taxus fuana Nan Li \& R.R. Mill (Taxaceae) based on morphological and molecular data. Taxon 57, 211-222.

Sheeja, G., Jyotsna, S., Vern, L.Y., 2009. Genetic diversity of the endangered and narrow endemic Piperia yadonii (Orchidaceae) assessed with ISSR polymorphisms. Am. J. Bot. 96, 2022-2030.

Silva, V., Póvoa, O., Espírito-Santo, M.D., Vasconcelos, T., Monteiro, A., 2009. Mentha cervina communities in Portugal. Lazaroa 30, 73-79.

Smith, J.F., Bateman, T.A., 2002. Genetic differentiation of rare and common varieties of Eriogonum shockleyi (Polygonaceae) in Idaho using ISSR variability. West N. Am. Naturalist 62, 316-326.

Tarayre, M., Thompson, J.D., 1996. Population genetic structure of the gynodioecious Thymus vulgaris (Labiateae) in Southern France. J. Evol. Biol. 10, 157-174.

Travis, S.E., Maschinski, J., Keim, P., 1996. An analysis of genetic variation in Astragalus cremnophylax var. cremnophylax, a critically endangered plant, using AFLP markers. Mol. Ecol. 5, 735-745.

Tutin, T.G., Heywood, V.H., Burges, N.A., Moore, D.M., Valentine, D.H., Walters, S.M., Webb, D.A., 1972. Flora Europaea. In: Diapensiaceae to Myoporaceae, vol. 3. Cambridge University Press, Cambridge.

Vekemans, X., Beauwens, T., Lemaire, M., Roldan-Ruiz, I., 2002. Data from amplified fragment length polymorphism (AFLP) markers show indication of size homoplasy and of a relationship between degree of homoplasy and fragment size. Mol. Ecol. 11, 139-151.

Vicente, M.J., Segura, F., Aguado, M., Migliaro, D., Franco, J.A., Martínez-Sánchez, J.J., 2011. Genetic diversity of Astragalus nitidiflorus, a critically endangered endemic of SE Spain, and implications for its conservation. Biochem. Syst. Ecol. 39, 175-182.

Vinceti, B., Van Breuge, P., Amaral, W., 2004. The practical implications of research outputs from forest genetic studies. In: Vinceti, B., Amaral, W., Meilleur, B. (Eds.), Challenges in Managing Forest Genetic Resources for Livelihoods. International Plant Genetic Resources Institute, pp. $245-267$.

Wang, C., Zhang, H., Qian, Z.Q., Zhao, G.F., 2008. Genetic differentiation in endangered Gynostemma pentaphyllum (Thunb.) Makino based on ISSR polymorphism and its implications for conservation. Biochem. Syst. Ecol. 36, 699-705.

Williams, J.G.K., Kubelik, A.R., Livak, K.J., Rafalski, J.A., Tingey, S.V., 1990. DNA polymorphisms amplified by arbitrary primers are useful as genetic markers. Nucleic Acids Res. 18, 6531-6535.

Xia, T., Chen, S., Chen, S., Zhang, D., Zhang, D., Gao, Q., Ge, X., 2007. ISSR analysis of genetic diversity of the Qinghai-Tibet Plateau endemic Rhodiola chrysanthemifolia (Crassulaceae). Biochem. Syst. Ecol. 35, 209-214.

Xiao, L.Q., Ge, X.J., Gong, X., Hao, G., Zheng, S.X., 2004. ISSR variation in the endemic and endangered plant Cycas guizhouensis (Cycadaceae). Ann. Bot. (Lond) $94,133-138$.

Xiao, W., Hong-Lin, C., Yun-Sheng, J., Wan-Hui, Y., Xue-Jun, G., Feng, L., 2008. Population genetic structure of Camellia nitidissima (Theaceae) and conservation implications. Bot. Stud. 49, 147-153.

Yeh, F.C., Yang, R., Boyle, T., 1997. POPGENE Version 1.32. Ag/For Molecular Biology and Biotechnology Centre. University of Alberta and Center for International Forestry Research.

Zhang, D.Q., Gao, L.M., Yang, Y.P., 2010. Genetic diversity and structure of a traditional Chinese medicinal plant species, Fritillaria cirrhosa (Liliaceae) in southwest China and implications for its conservation. Biochem. Syst. Ecol. 38, 236-242.

Zhou, T.H., Qian, Z.Q., Li, S., Guo, Z.G., Huang, Z.H., Liu, Z.L., Zhao, G.F., 2010. Genetic diversity of the endangered Chinese endemic herb Saruma henryi Oliv. (Aristolochiaceae) and its implications for conservation. Popul. Ecol. 52, 223-231.

Zietkiewicz, E., Rafalski, A., Labuda, D., 1994. Genome fingerprinting by simple sequence repeat (SSR)-anchored polymerase chain reaction amplification. Genomics 20, 176-183. 